\title{
TOPIC-FOCUS ARTICULATION OF ISOTOPY
}

\author{
Radim SovA \\ Masaryk University, Brno
}

\begin{abstract}
En): The paper deals with linguistic phenomena at suprasentential level. In particular, it looks into how textual analysis can be enhanced by supplementing the Parisian programme of interpretive semantics, as devised by François Rastier, namely his theory of isotopies, with elementary aspects of topic-focus articulation (TFA), as well as contextual boundness (CB) and contextual non-boundness $(\mathrm{CN})$, as elaborated within the Praguian linguistic tradition (V. Mathesius, P. Sgall, E. Hajičová, F. Daneš, J. Firbas), and how the descriptive power of the former can be increased by the latter. In this respect, it is argued that two types of TFA phenomena interact during any process of textual interpretation: those of topic-focus articulation at the level of sentence, conceiving lexical morphs as thematic (T) and/or rhematic (R), as well as contextually bound (CB) and/or contextually non-bound $(\mathrm{CN})$, and those of topic-focus articulation at the level of isotopy, with each isotopy being conceived as structured around a center (an abstract semantic unit) and periphery (a span of concrete utterances). Two types of such interaction are described, each defined by either correlation, or non-correlation of the $\mathrm{CB}$ and $\mathrm{CN}$ semes at the levels of isotopy and sentence, respectively: thematic-rhematic isotopy, induced by co-occurrence of the $\mathrm{CB}$ seme of the center and the $\mathrm{CB}$ seme of the periphery; and thematic-rhematic allotopy (i.e. non-isotopy), induced by co-occurrence of the CB seme of the center and the $\mathrm{CN}$ seme of the periphery. Since topic-focus isotopies and allotopies can be perceived as members of privative oppositions, a tentative system of such oppositions is presented, based on linguistic analyses of selected European Commission texts drafted in English and their Czech translations. The author's ultimate intention is to show that the semantic features of topic-focus articulation at the sentential and suprasentential levels are both structurally parallel and functionally complementary.
\end{abstract}

Résumé (Fr): Un résumé détaillé en français se trouve à la fin du texte.

Keywords (En): Center and Periphery, Cohesion, Contextual Boundness, Contextual NonBoundness, Interpretive Semantics, Isotopy, Rheme, Seme, Thematic Progression, Theme, Topic-Focus Articulation

The present paper deals with linguistic phenomena at suprasentential level. In particular, it looks into how textual analysis can be enhanced by supplementing the programme of interpretive semantics, as devised by François Rastier (cf. RASTIER, 1987, 2001), namely his theory of isotopies, with elementary aspects of topic-focus articulation (TFA), as well as contextual boundness (CB/cb) and contextual non-boundness $(\mathrm{CN} / \mathrm{cn})$, as elaborated within the Prague linguistic tradition (cf. MATHESIUS, 1924, 1975 ; SGALL, 1967 ; HAJIČOVÁ, 1973, 1975 ; SGALl, HAJIČOVÁ, BuRÁŇOVÁ, 1980 ; DANEŠ, 1974, 1985 ; FIRBAS, 1992 ; DUŠKOVÁ, 1999). 


\section{Theoretical Background}

Rastiers's interpretive semantics follows the Saussurean and Hjelmslevian traditions, working with linguistic signs (morphemes) as bilateral units theoretically conceivable as the relation of a unit of form (morph) and a unit of meaning (sememe). The minimum linguistic signs are perceived as both units of the abstract language system, each bearing its proper meaning, and units of a particular text, the co-occurrence of which establishes a particular contextual sense. Interpretive semantics is a microsemantics, i.e. semantics applying componential analysis (analyse componentielle) to the analysis of texts. However, unlike its North American pioneers (KATZ, FODOR, 1963 ; KATZ, POSTAL, 1964), it follows and further elaborates the tradition of European, chiefly French and francophone semantics (POTTIER, 1992 ; GREIMAS, 1986 ; COŞERIU, 1980). As a result, its minimum units are not referred to as components but semes, representing a more narrowly defined type of textual components. These are defined as four types of elementary units of grammatical and lexical meaning arranged, according to their semantic value, into two binary classes : generic vs. specific semes, representing an opposition based on relations inside a semantic class, as well as inherent vs. afferent semes, representing an opposition based on a twofold and parallel existence of the morpheme as a unit of the language system and as a unit of the discourse. The relations of semes within actual texts are examined through isotopies. This term was introduced into linguistics by GREIMAS (1986) to express the identity or similarity of semantic units and their pertinence to a certain semantic field, part or place within a text based on purely linguistic criteria. As a result, structural semantics has brought linguistic analysis below the level of word and beyond the level of sentence by focusing on the text. Isotopy has thus become a concept combining the two means of analysis into a single method of interpretation, the aim of which is to describe phenomena at the macrosemantic level using phenomena at the microsemantic level. In Rastier's programme of interpretive semantics, isotopy is defined as the effect of repeated co-occurrence of the same semes in the text. This effect is considered to establish cohesion of the text, depending on the semantic relations within it and constituting as such a phenomenon of a chiefly linguistic order.

\section{Theoretical Framework}

In the presented theoretical framework, two types of TFA phenomena constantly interact during the process of textual interpretation: (i) phenomena of topic-focus articulation at sentential level $\left(\mathrm{TFA}_{\mathrm{s}}\right)$, conceiving lexical morphs as topical (t) and/or focal (f), as well as contextually bound (cb) and/or contextually non-bound (cb) ; and (ii) phenomena of topic-focus articulation at suprasentential level, namely at the level of isotopy $\left(\mathrm{TFA}_{\mathrm{i}}\right)$, which, for the purpose of the TFA analysis, is structured around a center and a periphery.

The center of isotopy is defined as an abstract semantic unit ensuring cohesion of the text or its parts, while the periphery represents a set of morphemes (both lexical and grammatical) by which such a text or its parts are constituted in a particular text. Semantically, the center is described by means of an isotopic theme. This theme is constituted by a central seme or a set of central semes passing through the periphery of the text where it undergoes specific semantic 
processes, being either actualised, i.e. semantically foregrounded, or virtualised, i.e. semantically backgrounded. It is considered to be an abstract unit (isotopeme), or the underlying structural description of an isotopy, which is fully describable in the global context only - in the functional system of the whole text subject to linguistic analysis, and which can only be empirically examined through a set of local occurrences, representations or morphemic derivatives of the central isotopeme (isotopes).

Depending on the type of isotopic theme, two types of text are defined. On the one hand, there are texts with a deduced isotopy (mostly technical texts), the isotopic theme of which is known from the outset of the analysis (hereinafter referred to as "D-Texts"). Their center is by default considered topical and contextually bound, whereas their periphery topical and/or focal, as well as contextually bound and/or contextually non-bound. On the other hand, there are texts with an induced isotopy (mostly literary texts), the isotopic theme of which is unknown (or vague or transformed, as by a metaphor) from the outset of the analysis (hereinafter referred to as "I-Texts"). Their center is by default considered focal and contextually non-bound, whereas their periphery topical and/or focal, as well as contextually bound and/or contextually non-bound.

The center and the periphery of isotopy are attributed a specific semic structure. In the abstract language system, this structure is described by means of a complex seme $/ \mathrm{T}_{\mathrm{CB} / \mathrm{CN}} \& \mathrm{~F}_{\mathrm{CN} / \mathrm{CB}} /$. In a particular type of text, it is represented by elementary values of the complex seme, i.e. $/ \mathrm{T}_{\mathrm{CB}} /$ of the center of D-Texts, or $/ \mathrm{F}_{\mathrm{CN}} /$ of the center of I-Texts, as well as $/ \mathrm{t}_{\mathrm{cb}} /, / \mathrm{t}_{\mathrm{cn}} /, / \mathrm{f}_{\mathrm{cn}} /$, or $/ \mathrm{f}_{\mathrm{cb}} /$ of the periphery, assigned according to a particular context. This approach to sematic classification seems to be consistent with Rastier's semantic theory, allowing for semes with a complex internal structure, as in the case of Latin bi-gender nouns (substantiua communia) of the type canis albus vs. canis alba, the complex seme of which (/MASC/\&/FEM/) is only differentiated and attributed as either /MASC/, or /FEM/ in a given context.

As already mentioned, the $\mathrm{TFA}_{\mathrm{i}}$ semes are seen in constant interaction with the $\mathrm{TFA}_{\mathrm{s}}$ semes. Two types of such interaction are considered, depending on whether or not the features of contextual boundness and contextual non-boundness defined at the level of isotopy and sentence, respectively, co-occur : (i) topic-focus isotopy, defined as the effect of co-occurrence of the feature /CB/ (or /CN/) of the center and the feature $/ \mathrm{cb} /(\mathrm{or} / \mathrm{cn} /)$ of the periphery and reflected, at the level of surface representation, by an uninterrupted thematic progression; or (ii) topic-focus allotopy (i.e. "non-isotopy"), defined as the effect of co-occurrence of the feature $/ \mathrm{CB} /$ (or $/ \mathrm{CN} /)$ of the center and the feature $/ \mathrm{cn} /($ or $/ \mathrm{cb} /)$ of the periphery and reflected, at the level of surface representation, by an interrupted thematic progression. The defining feature enabling to determine whether it is isotopy or allotopy that asserts itself is the identity of context borne by the center and periphery.

\section{Textual Analysis}

The sematic makeup of the center and periphery enables to identify, for each of the two types of text defined above, a set of TFA relations comprising two isotopies and two allotopies : 


\begin{tabular}{|l|l|}
\hline D-Texts & Periphery: \\
\hline \multirow{5}{*}{ Center $: / \mathrm{T}_{\mathrm{CB}} /$} & (i) $/ \mathrm{t}_{\mathrm{cb}} / \rightarrow$ isotopy \\
\cline { 2 - 2 } & (ii) $/ \mathrm{t}_{\mathrm{cn}} / \rightarrow$ allotopy \\
\cline { 2 - 2 } & (iii) $/ \mathrm{f}_{\mathrm{cb}} / \rightarrow$ isotopy \\
\cline { 2 - 2 } I-Texts & (iv) $/ \mathrm{f}_{\mathrm{c} n} / \rightarrow$ allotopy \\
\hline \multirow{5}{*}{ Center $: / \mathrm{F}_{\mathrm{CN}} /$} & Periphery: \\
& (i) $/ \mathrm{f}_{\mathrm{c}} / \rightarrow$ isotopy \\
\cline { 2 - 2 } & (ii) $/ \mathrm{f}_{\mathrm{cb}} / \rightarrow$ allotopy \\
\cline { 2 - 2 } & (iii) $/ \mathrm{t}_{\mathrm{cn}} / \rightarrow$ isotopy \\
\cline { 2 - 2 } & (iv) $/ \mathrm{t}_{\mathrm{cb}} / \rightarrow$ allotopy \\
\hline
\end{tabular}

The theoretically postulated TFA cases have so far been empirically well established for the D-Texts only. They can be supported by the following examples based on translations of selected D-Texts from English into Czech. In addition, certain conclusions have been drawn on the relations and distribution of isotopies and allotopies within the set of D-Texts.

\subsection{Type $D-i$ : : $D-i v$}

\section{ORI}

For national or local purposes, Toll Chargers may keep or set up their specific national or local services, with manual, automatic or electronic systems. EETS is a complementary service to the national or local electronic toll services of the Member States for the payment of toll, but where Member States have toll systems, they shall take the necessary measures to increase the use of electronic toll systems and endeavour to ensure that at least $50 \%$ of traffic flow in each toll station can use electronic toll systems.

\begin{tabular}{|c|c|}
\hline TRA $_{\text {iso }}$ & TRA $_{\text {allo }}$ \\
\hline 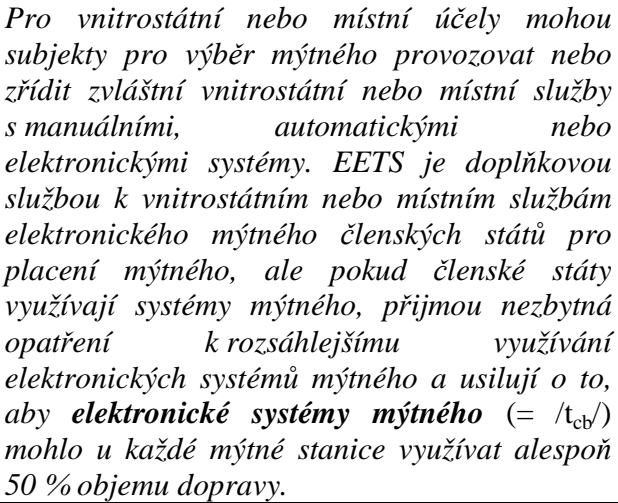 & 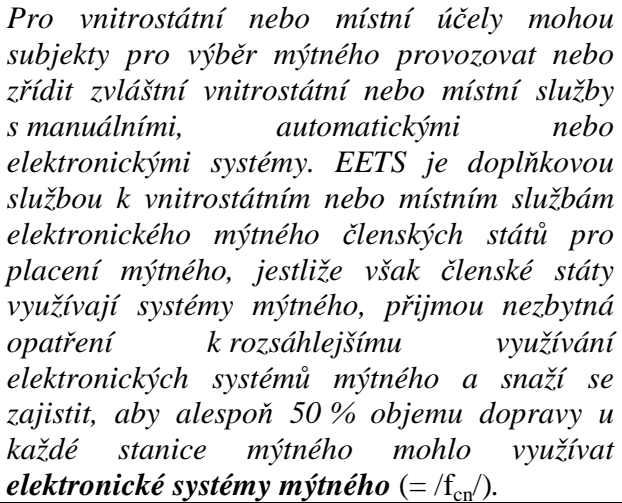 \\
\hline
\end{tabular}

In the Commission Decision on the European Electronic Toll service, an isotopeme "European electronic toll service" can be established deductively, with

\footnotetext{
${ }^{1}$ Commission Decision 2009/750/EC of 6 October 2009 on the definition of the European Electronic Toll Service and its technical elements (OJ L 268, 13.10.2009, p. 11-29).
} 
the morphemic derivative "electronic toll systems" as its isotope. In the Czech translation, the peripheral Czech morph elektronické systémy mýtného constitutes an isotopy (type $D-i$ ) with the central morpheme (attributed the seme $/ \mathrm{T}_{\mathrm{CB}} /$ ), if its sememe includes the feature $/ \mathrm{t}_{\mathrm{cb}} /$ (being placed in the topical part of the utterance, before the finite verb, and not bearing the sentence stress) ; however, if the same morph is incorrectly attributed the feature $/ \mathrm{f}_{\mathrm{cn}} /$ (being placed in the focal part of the utterance, after the finite verb, and bearing the sentence stress), it constitutes an allotopy (type $D-i v$ ).

In distributional terms, cases like the one above, based on the systemic opposition of isotopy and allotopy, are referred to as marked in the presented theoretical framework. Markedness is defined in relation to textual co-occurrences of the different TFA types, referring to the presence of TFA features disturbing textual cohesion. In functional terms, this opposition is well supported within the language system, being reflected by two peculiar surface structures : one respecting, and the other one disturbing, the topic-focus articulation by which textual cohesion is ensured.

\subsection{Type $D$-iii : : $D$-iv}

\section{ORI}

In the interest of sound administration and budget management, Member States implementing a School Fruit Scheme should apply for Community aid on an annual basis.

\begin{tabular}{|c|c|}
\hline $\mathbf{T R A}_{\text {iso }}$ & TRA $_{\text {allo }}$ \\
\hline $\begin{array}{l}\text { V zájmu řádné správy a řízení rozpočtu by měly } \\
\text { členské státy provádéjící projekt „,Ovoce do } \\
\text { škol“ žádat o podporu Společenství každý rok } \\
\left(=/ \mathrm{f}_{\mathrm{cb}} /\right) \text {. }\end{array}$ & $\begin{array}{l}\text { V zájmu řádné správy a řízení rozpočtu by měly } \\
\text { členské státy provádějící projekt „Ovoce do } \\
\text { škol“ každý rok žádat o podporu Společenství } \\
\left(=/ \mathrm{f}_{\mathrm{cn}} /\right) \text {. }\end{array}$ \\
\hline
\end{tabular}

In the Commission regulation providing for the Community aid for supporting fruit and vegetables in the framework of a School Fruit Scheme ${ }^{3}$, an isotopeme "Community aid for supplying fruit and vegetables, processed fruit and vegetables and banana products to children in educational establishments, in the framework of a School Fruit Scheme" can be established deductively, with the elliptic morphemic derivative "Community aid" as its isotope. In the Czech translation, the peripheral Czech morph podpora Společenství is found to constitute an isotopy (type $D$-iii) with the central morpheme (attributed the seme $/ \mathrm{T}_{\mathrm{CB}} /$ ), as long as its sememe contains the feature $/ \mathrm{f}_{\mathrm{cb}}$ / (being placed after the finite verb and not bearing the sentence stress) ; nevertheless, if the same morph is incorrectly attributed the feature $/ \mathrm{f}_{\mathrm{cn}} /$ (being placed after the finite verb and bearing the sentence stress), it results in an allotopy (type $D-i v$ ).

\footnotetext{
${ }^{2}$ For the purpose of the present section, the following graphical conventions apply: «isotopic theme/ isotopeme », "lexical unit/morpheme/isotope", morph, /seme/.

${ }^{3}$ Commission Regulation (EC) No 288/2009 of 7 April 2009 laying down detailed rules for applying Council Regulation (EC) No 1234/2007 as regards Community aid for supplying fruit and vegetables, processed fruit and vegetables and banana products to children in educational establishments, in the framework of a School Fruit Scheme (OJ L 94, 08.04.2009, p. 38-47).
} 
This is yet another case of a marked, isotopic-allotopic opposition that is well supported within the language system, being based on the functional identity of the semantic feature of focus $\left(/ \mathrm{f}_{\mathrm{x}} /\right)$.

\subsection{Type $D-i:: D$-iii}

\begin{tabular}{|c|c|}
\hline $\mathbf{T R A}_{\text {iso }}$ & $\begin{array}{l}\text { podpora Společenství : : } \\
\text { členské státy provádějící } \\
\text { projekt „Ovoce do škol“ }\end{array}$ \\
\hline $\begin{array}{l}\text { A. V zájmu řádné správy a řizení rozpočtu by o podporu } \\
\text { Společenství měly žádat členské státy provádéjicí projekt „Ovoce } \\
\text { do škol“ každý rok. }\end{array}$ & $/ \mathrm{T}_{\mathrm{CB}} /:: / \mathrm{f}_{\mathrm{cb}} /$ \\
\hline $\begin{array}{l}\text { B. V zájmu řádné správy a řizení rozpočtu by o podporu } \\
\text { Společenstvi měly členské státy provádějicí projekt „ovoce do } \\
\text { škol"žádat každý rok. }\end{array}$ & $/ \mathrm{T}_{\mathrm{CB}} /:: / \mathrm{t}_{\mathrm{cb}} /$ \\
\hline $\begin{array}{l}\text { C. V zájmu řádné správy a ř́zení rozpočtu by členské státy } \\
\text { provádéjicí projekt „Ovoce do škol“ měly o podporu Společenství } \\
\text { žádat každý rok. }\end{array}$ & $/ \mathrm{T}_{\mathrm{CB}} /:: / \mathrm{t}_{\mathrm{cb}} /$ \\
\hline
\end{tabular}

Another way of analysing the aforementioned isotopeme "Community aid for supplying fruit and vegetables, processed fruit and vegetables and banana products to children in educational establishments, in the framework of a School Fruit Scheme" is to regard it as a juxtaposition of its component morphemes "Community aid" ( $\leftarrow$ "Community aid for supplying fruit and vegetables, processed fruit and vegetables and banana products to children [...]") and "Member States implementing a Fruit School Scheme" ( $\leftarrow$ "[...] educational establishments, in the framework of a School Fruit Scheme"). Both syntagms are separated by the finite verb (or one of its morphological constituents), drawing the boundary between their topical and focal constituents. Depending on the different positions of the Czech predicate morphs, both morphemic derivatives receive different semantic features in terms of $\mathrm{TFA}_{\mathrm{i}}$ : while Case $\mathrm{A}$ is analogical to the one examined above (type $D$-iii), with the exception of the two derived syntagms showing an inverted surface order, Cases $\mathrm{B}$ and $\mathrm{C}$, whose surface order is also inverted, represent an isotopy of the type $D-i$. Examples A, B and C suggest that the isotopy between the center and the periphery (i.e. tectogrammatical representation) is not necessarily restricted to a single surface order (i.e. fenogrammatical representation).

In distributional terms, the three examples suggest that unlike the marked oppositions examined so far, the opposition $D-i:: D$-iii is unmarked : rather than involving two constituents of a different order (an isotopy and an allotopy) it involves two constituents of the same order (two isotopies). In the presented theoretical framework, unmarkedness is defined in relation to textual cooccurrences of the different TFA types, referring to the absence of TFA features disturbing textual cohesion. In functional terms, the opposition is well supported within the language system, being based on the functional identity of the semantic feature of contextual boundness $\left(/ \mathrm{x}_{\mathrm{cb}} /\right)$. 


\subsection{Type $D-i:$ : $D-i i$}

\section{ORI}

Without being exhaustive, the following can be mentioned as examples of services covered by the Directive: the activities of most of the regulated professions (such as legal and fiscal advisers, architects, engineers, accountants, surveyors)...

Orientačně lze jako př́klady služeb, na něž se
směrnice vztahuje $\left(=/ \mathrm{t}_{\mathrm{cb}} /\right)$, uvést činnosti většiny regulovaných povolání (např. Právní a daňoví poradci, architekti, inženýři, účetní, znalci)... TRA $_{\text {allo }}$ Orientačně lze jako př́klady služeb, na něž se vztahuje směrnice $\left(=/ \mathrm{t}_{\mathrm{cn}}\right)$, uvést činnosti většiny regulovaných povolání (např. Právní a daňoví poradci, architekti, inženýři, účetní, znalci)...

In the Handbook on Implementation of the Services Directive ${ }^{4}$, an isotopeme "Services Directive" can be established deductively, with the elliptic morphemic derivative "Directive" as its isotope. In the Czech translation, the corresponding peripheral Czech morph smerrnice constitutes an isotopy (type $D-i$ ) with the central morpheme (attributed the seme $/ \mathrm{T}_{\mathrm{CB}} /$ ), if its sememe contains the feature $/ \mathrm{t}_{\mathrm{cb}} /$ (being placed before the finite verb of the principal clause and before the finite verb of the subordinate clause and not bearing the sentence stress in any of the clauses) ; however, if the same morph is incorrectly attributed the feature $/ \mathrm{t}_{\mathrm{cn}} /$ (being placed before the finite verb of the principal clause and after the verb of the subordinate clause and bearing the sentence stress in the subordinate clause), it constitutes an allotopy (type $D$-ii).

This is yet another case of a marked, isotopic-allotopic opposition that is well supported within the language system, being based on the functional identity of the semantic feature of topic $\left(/ t_{x} /\right)$.

\footnotetext{
${ }^{4}$ Available at: http://ec.europa.eu/internal_market/services/docs/servicesdir/guides/handbook_en.pdf .
} 


\section{ORI}

Thus, within the meaning of the EC Treaty and the Services Directive, in order to constitute a "service" an activity has to be a self-employed activity, i.e. it has to be supplied by a provider (which could be a natural or a legal person) outside the ties of a contract of employment. Moreover, the activity must normally be provided for remuneration; in other words, it must be of an economic nature. This has to be assessed on a case-by-case basis for each activity. The mere fact that an activity is provided by the State, by a State body or by a non-profit organisation does not mean that it does not constitute a service within the meaning of the EC Treaty and the Services Directive.

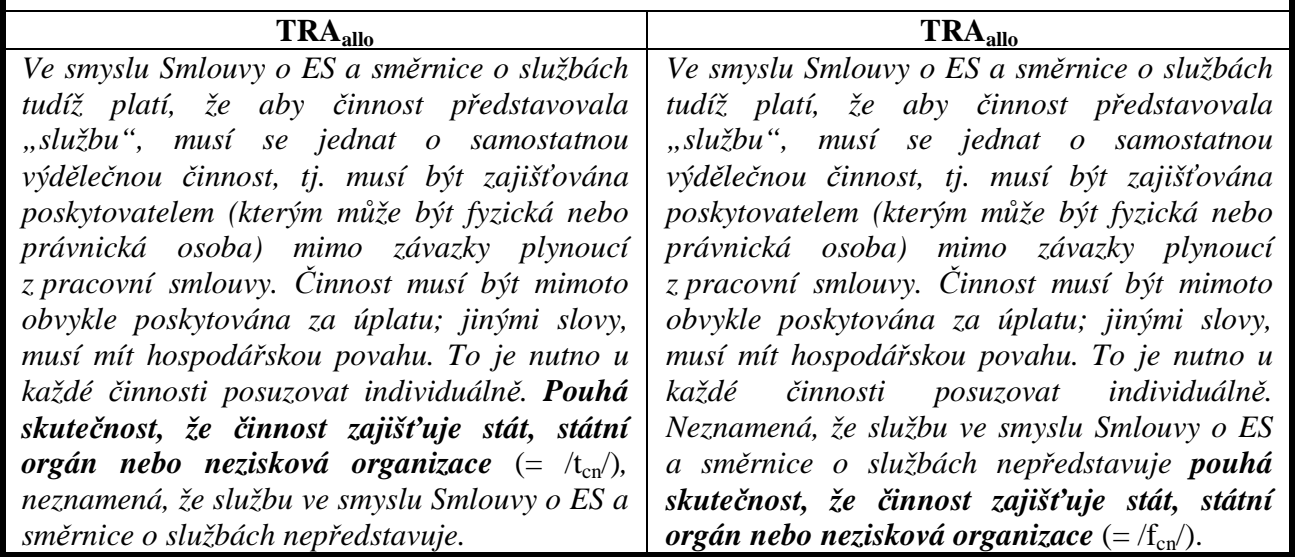

In the Handbook mentioned above, the deductively established isotopeme "Services Directive" can be construed with another isotope, namely the elliptic morphemic derivative "service". This is the principal topic of the passage taken from the chapter on the definition of service as a binding legal term. The Czech phrase in bold can be attributed either the seme $/ \mathrm{t}_{\mathrm{cn}} /$ (being placed before the finite verb and not bearing the sentence stress of the principal clause), or the seme $/ \mathrm{f}_{\mathrm{cn}} /$ (being placed after the finite verb and bearing the sentence stress of the principal clause). The left-column allotopy, actually attested, allows for a continuous enumeration of the members of the same semantic category, i.e. the types of activity classified as types of service by the Handbook, which is something the right-column allotopy, created for the purpose of the present analysis, fails to do, with the result of being little understandable and potentially misleading. In terms of TFA, within the quoted section, the former allotopy disturbs the thematic progression while respecting the sequence of the semes $/ \mathrm{f}_{\mathrm{cn}} /$, whereas the latter allotopy respects the thematic progression while disturbing the sequence of the semes $/ \mathrm{f}_{\mathrm{cn}} /$. In this way, the semes $/ \mathrm{t}_{\mathrm{cn}} /$ of the morphemes included in the leftcolumn phrase in bold ensure semantic identity, through the seme $/ \mathrm{cb} /$, with the semes $/ \mathrm{f}_{\mathrm{cn}} /$ of the morphemes included in the previous phrases (such as "selfemployed activity", "provider (a natural or a legal person)" or "remuneration"). It is here where the tools of interpretive semantics step in to establish that the semes $/ \mathrm{t}_{\mathrm{cn}} /$ are correlated with the seme /public domain/ and the semes $/ \mathrm{f}_{\mathrm{cn}} /$ with the seme /private domain/, the lexical units identified as belonging either to the "public domain", or the "private domain" being regarded as different manifestations of 
the single isotope "service". This brings us to the conclusion that allotopies of the type $D-i i$ and $D-i v$ have a potential to enter into unmarked oppositions, by way of analogy to the unmarked oppositions into which isotopies can enter. From the leftcolumn case of allotopy it further follows that textual cohesion can be achieved not only through a sequence of topics and foci but also through a sequence of contextually non-bound elements.

The opposition is well supported within the language system, being based on the functional identity of the semantic feature of contextual non-boundness $\left(/ \mathrm{x}_{\mathrm{cn}} /\right)$.

\section{Conclusion}

The set of TFA oppositions and their relations examined so far may be charted as follows :

\begin{tabular}{|c|c|c|c|}
\cline { 2 - 2 } \multicolumn{1}{c|}{} & $D-i i i\left(/ \mathbf{f}_{\mathbf{c b}} /\right)$ & ISO-ALLO & $D-i v\left(/ \mathbf{f}_{\mathbf{c n}} /\right)$ \\
\hline$D-i\left(/ \mathbf{t}_{\mathbf{c b}} /\right)$ & ISO & & ISO-ALLO \\
\hline ISO-ALLO & \multicolumn{1}{|c|}{} \\
\hline$D-i i\left(/ \mathbf{t}_{\mathbf{c n}} /\right)$ & $\mathrm{X}$ & ALLO \\
\hline
\end{tabular}

The internal structure of the TFA oppositions identified in D-Texts shows that, formally, these are of two types : absolutely privative, i.e. the unmarked opposition $D-i:: D-i v$, where the semantic features of both topicality/focality and contextual boundness/non-boundness stand in a mutually exclusive opposition ; and relatively privative, i.e. the other unmarked and/or marked oppositions, where the semantic features of either topicality/focality (type $D$ - $i:: D$-iii and $D$ - $i i:: D$ $i v$ ), or contextual boundness/non-boundness (type $D$ - $i:: D$ - $i i$ and $D$-iii : : $D$-iv) stand in mutually exclusive oppositions. The last and least opposition $D$-ii : : $D$-iii - an absolutely privative and unmarked opposition of the semes $/ \mathrm{t}_{\mathrm{cn}} / \mathrm{a} / \mathrm{f}_{\mathrm{cb}} /$ - has not been attested in the author's empirical research into D-Texts but rather deduced from the systemic potential of the set of TFA oppositions. Its empirical absence may not be accidental, as it seems to be underpinned by at least some structural and distributional reasons.

There is a difference between the marked and unmarked TFA oppositions in terms of the degree of textual cohesion (textuality) to which they contribute : whereas the marked oppositions bear a low degree of textuality, as one constituent of their pairs is always disturbing the textual cohesion by interrupting a sequence of TFA semes, the unmarked oppositions show a high degree of textuality, as both constituents of their pairs contribute to the textual cohesion by respecting a sequence of certain TFA semes, i.e. either a thematic progression, or a progression of contextually non-bound semes.

The author's intention was to show, by sole reference to the D-Texts, that the semantic features of TFA defined at the levels of sentence (TFA $)$ and isotopy $\left(\mathrm{TFA}_{\mathrm{i}}\right)$ are not only structurally parallel but also functionally complementary. 
Therefore, the study of TFA phenomena at the sentential and suprasentential levels seems to be of high relevance for textual interpretation. For whereas the former are relevant for the interpretation of single utterances only, it is their interaction with the latter that is pertinent to the interpretation of the discourse as a whole. As a consequence - and in the language of the presented theoretical framework - a correct TFA analysis and description of individual utterances allows for proper correlation of their signs to the isotopy or isotopies passing through a part of the text which the individual utterances are deemed to constitute. In this way, the descriptive power of the programme of interpretive semantics extended with the TFA phenomena seems well enhanced.

\section{BIBLIOGRAPHY}

COŞERIU Eugenio (1980), Textlinguistik: eine Einführung, ed. ALBRECHT Jörn, Tübingen, Narr.

DANEŠ František (1974), Functional Sentence Perspective and the Organization of the Text, Papers on Functional Sentence Perspective, Praha, Academia, p. 106-128.

DANEŠ František (1985), Věta a text, Praha, Academia.

DuŠKOVÁ Libuše (1999), Studies in the English Language. Part 1, Part 2, Praha, Karolinum.

FIRBAS Jan (1992), Functional sentence perspective in written and spoken communication, Cambridge University Press.

GREIMAS Algirdas Julien (1986), Sémantique structurale, Paris, Presses Universitaires de France.

HajIČOvÁ Eva (1973), Negation and Topic vs. Comment, Philologica Pragensia 16, p. 81-93.

HAJIČOVÁ Eva (1975), Negace a presupozice ve významové stavbě věty, Praha, Academia.

KATZ Jerrold J., FodOR Jerry A. (1963), The Structure of Semantic Theory, Language 39, p. 170-210.

Katz Jerrold J., Postal Paul M. (1964), An Integrated Theory of Linguistic Description, Cambridge (Mass.), MIT Press.

MATHESIUS Vilém (1924), Několik poznámek o funkci podmětu v moderní angličtině, Časopis pro moderní filologii 10, p. 244-248.

MATHESIUS Vilém (1975), A Functional Analysis of Present Day English on a General Linguistic Basis, ed. VACHEK Josef, The Hague - Paris, Mouton (Janua linguarum, Series Practica 208) \& Praha, Academia.

PotTIER Bernard (1992), Sémantique générale, Paris, Presses Universitaires de France.

RASTIER François (1987), Sémantique interprétative, Paris, Presses Universitaires de France.

RASTIER François (2001), Arts et sciences du texte, Paris, Presses Universitaires de France.

SGALl Petr (1967), Functional Sentence Perspective in a Generative Description, Prague Studies in Mathematical Linguistics 2, p. 203-225. 
Sgall Petr, HaJIČOvÁ Eva, BuRÁŇOvÁ Eva (1980), Aktuální členění věty v češtině, Praha, Academia.

\section{RÉSUMÉ EN FRANÇAIS}

L'article traite des phénomènes linguistiques au niveau dépassant celui de la phrase. En particulier, il examine comment l'analyse textuelle peut être améliorée en complétant le programme de la sémantique interprétative, comme imaginé par François Rastier (cf. RASTIER, 1987, 2001), à savoir sa théorie des isotopies, par des aspects élémentaires de l'articulation thématico-rhématique (ATR), ainsi que de la liaison et de la nonliaison contextuelles, tels que élaborés dans la tradition linguistique pragoise (cf. MATHESIUS, 1924, 1975 ; SGALL, 1967 ; HAJIČOVÁ, 1973, 1975 ; SGALl, HAJIČOVÁ, BURÁŇOVÁ, 1980 ; DANEŠ, 1974, 1985 ; FIRBAS, 1992 ; DUŠKOVÁ, 1999).

Il est présumé que deux types de phénomènes de l'ATR interagissent lors de toute interprétation textuelle : d'une part, il y a des phénomènes d'articulation thématico-rhématique au niveau de la phrase $\left(\mathrm{ATR}_{\mathrm{p}}\right)$, concevant des morphes lexicaux comme thématiques ( $\mathrm{T}$ ) et/ou rhématiques (R), ainsi que contextuellement liés (CL) et/ou contextuellement non liés $(\mathrm{CN})$; d'autre part, il y a des phénomènes d'articulation thématico-rhématique au niveau de l'isotopie $\left(A T R_{\mathrm{i}}\right)$, cette dernière étant définie comme l'effet de la cooccurrence répétée de morphèmes dans le texte et étant, dans le but de l'analyse de l'ART, structurée autour d'un centre et d'une périphérie. Dans le cadre théorique présenté, le centre d'isotopie est défini comme l'unité abstraite sémantique assurant la cohésion du texte ou ses parties tandis que la périphérie représente un ensemble de morphèmes (lexicaux et grammaticaux) par lequel un tel texte ou ses parties sont constitués et manifestés. Ầ cet égard, un autre sens est attribué à la notion de thème en dehors de celui du noyaux de la phrase, à savoir celui d'une valeur sémantique d'une isotopie particulière passant par le texte.

Par conséquent, deux types textuels sont définis : (i) des textes à isotopie déduite (textes essentiellement techniques au sens large du terme) dont le thème isotopique est connu dès l'abord de l'analyse (《textes D »); et (ii) des textes à isotopie induite (textes essentiellement littéraires au sens large du terme) dont le thème isotopique est inconnu (ou vague ou transformé, comme par une métaphore) dès l'abord de l'analyse («textes $I »)$. Le centre des « textes D » est par défaut considéré thématique et contextuellement lié (lui étant ainsi attribué le sème $/ \mathrm{T}_{\mathrm{CL}} /$ dans le cadre du programme de la sémantique interprétative étendu) tandis que le centre des « textes I » est par défaut considéré rhématique et contextuellement non lié (lui étant ainsi attribué le sème $/ \mathrm{R}_{\mathrm{CN}} /$ ). La périphérie des «textes $\mathrm{D}$ » est par défaut rhématique et contextuellement non liée $\left(/ \mathrm{R}_{\mathrm{CN}} /\right)$ alors que celle des «textes I », thématique et contextuellement liée $\left(/ \mathrm{T}_{\mathrm{CL}} /\right)$. Ces sèmes, défini au niveau de l'ATR ${ }_{\mathrm{I}}$, sont considérés d'être en interaction constante avec les sèmes définis au niveau de l'ATR $\mathrm{p}_{\mathrm{p}}$, c'est-à-dire le thème et le rhème de chaque énoncé constituant la périphérie concernée (ces derniers étant ainsi désignés comme des sèmes complexes $/ \mathrm{t}_{\mathrm{cl} / \mathrm{cn}} /$ et $/ \mathrm{r}_{\mathrm{c} / \mathrm{cn}} /$ dans le cadre théorique présenté).

En général, deux types d'interaction sont conçus, chacun étant déterminé par la corrélation des sèmes de liaison et ceux de nonliaison contextuelles considérés 
soit sémantiquement équivalentes, soit opposites au niveau de l'ATR $\mathrm{R}_{\mathrm{i}}$ et de $\mathrm{l}^{\prime} \mathrm{ATR}_{\mathrm{p}}$ : l'isotopie thématico-rhématique, définie comme l'effet de la cooccurrence des sèmes de liaison contextuelle (/CL/) ou ceux de non-liaison contextuelle $(/ \mathrm{CN} /)$ du centre et des sèmes sémantiquement équivalents de la périphérie (/cl/ et /cn/, respéctivement); l'allotopie (soit " nonisotopie ») thématico-rhématique, définie comme l'effet de la cooccurrence des sèmes de liaison contextuelle (/CL/) ou ceux de nonliaison contextuelle (/CN/) du centre et des sèmes sémantiquement opposites de la périphérie (/cn/ et /cl/, respéctivement). La fonction qui permet de postuler si c'est l'isotopie ou l'allotopie qui s'affirme dans un contexte donné est l'identité du contexte engendré par le centre et par la périphérie. Si l'identité du contexte central et du contexte périphérique s'impose, puis, selon le type du texte, deux cas de corrélation des sèmes susmentionnés peuvent être identifiés : la corrélation $/ \mathrm{CB} / /-/ \mathrm{cb} /$, constituant un cadre prédéfini, à savoir le contexte général des « textes $\mathrm{D}$ »; la corrélation $/ \mathrm{CN} /-/ \mathrm{cn} /$, constituant un cadre progressivement construit ou interprété, c'est à dire le contexte général des « textes I ».

L'intention de l'auteur est de montrer, en ne se référant qu'aux « textes $D$ », que les traits sémantiques au niveau de l'ATR $\mathrm{i}_{\mathrm{i}}$ et de $\mathrm{l}^{\prime} \mathrm{ATR}_{\mathrm{p}}$ sont structurellement parallèles aussi bien que fonctionnellement complémentaires. Ceci est principalement dû au fait que, bien que l'isotopie thématico-rhématique se traduise par une séquence ininterrompue de thèmes et de rhèmes au niveau de $\mathrm{l}^{\prime} \mathrm{ATR}_{\mathrm{p}}$, l'allotopie thématico-rhématique se produit lorsqu'une telle séquence a été interrompue, à savoir par l'application incohérente des règles de l'ATR ${ }_{p}$ dans un ou plusieurs énoncés constituant la séquence. Il en ressort que l'étude des phénomènes d'articulation thématico-rhématique au niveau phrastique et au niveau supraphrastique est très pertinente pour l'interprétation textuelle : tandis que les phénomènes de $l^{\prime} \mathrm{ATR}_{\mathrm{p}}$ sont propres à l'interprétation des énoncés individuels, c'est leur interaction avec des phénomènes de l'ATR $\mathrm{i}_{\mathrm{i}}$ qui est essentielle pour l'interprétation du discours dans son ensemble. Autrement dit, l'analyse et la description correcte des énoncés individuels au niveau de l'ATR permet une corrélation adéquate de leurs signes à l'isotopie ou à l'isotopies passant par le contexte par lequel ces énoncés mêmes sont constitués. De cette manière, la puissance descriptive de la sémantique interprétative semble bien augmentée. 